\title{
ADSORPTION OF CONGO RED USING Mg/Al HYDROTALCITE
}

\author{
Muhammad Said ${ }^{1}$, Neza Rahayu Palapa ${ }^{1 *}$ \\ ${ }^{1}$ Department of Chemistry, Faculty of Mathematics and Natural Science, Sriwijaya University \\ *Corresponding Author E-mail: Nezarahayn@gmail.com
}

\begin{abstract}
$\mathrm{Mg} / \mathrm{Al}$ hydrotalcite and $\mathrm{Mg} / \mathrm{Al}$ hydrotalcite intercalated with polyoxometalate $\mathrm{H}_{4}\left[\alpha-\mathrm{SiW}_{12} \mathrm{O}_{40}\right] \cdot \mathrm{nH}_{2} \mathrm{O}(1: 1)$ was synthesized and used as adsorbent colored-dye i.e. Congo red. Adsorption was conducted using batch system. The factor that influencing adsorption such as kinetic, thermodynamic, and $\mathrm{pH}$ was investigated. The results showed that kinetically adsorption of $\mathrm{Mg} / \mathrm{Al}$ intercalated polyoxometalate was faster than $\mathrm{Mg} / \mathrm{Al}$ hydrotalcite before intercalation. On the other side, thermodynamically adsorption using $\mathrm{Mg} / \mathrm{Al}$ hydrotalcite is higher than $\mathrm{Mg} / \mathrm{Al}$ hydrotalcite intercalated polyoxometalate. Probably due to high molecular size of Congo red can decresed the adsorption ability of $\mathrm{Mg} / \mathrm{Al}$ hydrotalcite after intercalated.
\end{abstract}

Keywords: hydrotalcite, polyoxometalate, intercalated, Congo red, adsorption

\section{INTRODUCTION}

Hydrotalcite has general formula $\left[\mathrm{M}^{2+}{ }_{(1-\mathrm{x})} \mathrm{M}^{3+}{ }_{\mathrm{x}}(\mathrm{OH})_{2}\right]\left(\mathrm{A}^{\mathrm{n}-}\right.$ $\mathrm{x} / \mathrm{nH}_{2} \mathrm{O}$. This layer materials contains divalent and trivalent matal cation with high flexibility cation exchange and esily synthesized in laboratory (Zhao, et.al, 2011). Application of hydrotalcite can be achived optimally by modification of these material.

The modification of hydotalcite for various applications is interesting due to ion exchange ability such as sensors, membranes, adsorbents, catalysts, and ion exchanges (Duan et.al, 2011).

Modification of hydrotalcite can be achived by intercalation using anion such as sulfate, carbonate, or nitrate. These anions are cations with small size (Asif et.al, 2017). In order to increase the ability of hydrotalcite as adsorbent, the use of macroanion is vital. Macroanions are rarely obtained in the nature or laboratory. Thus synthesis of macroanions for intercalant of hydrotalcite is intriguing research. Lesbani et.al $(2008,2015)$ was used polyoxometalates as macroanion for starting materials of ionic cystals and as catalysts. The advantages of polyoxometalate are high acidity, redox properties, high solubility depanding on counter ions, and various structures such as Keggin, Dawson, Anderson, and Lacunary types. Among these polyoxometalates, Keggin type is commonly used in many applications due to stability of these compound. Polyoxometalates were applied as intercalant in many layer double hydroxides materials like hydrotalcite (Jia et.al, 2015, Liu et.al, 2016).

In this research, hydrotalcite and hydrotalcite intercalated Keggin type polyoxometalate of $\mathrm{H}_{4}\left[\alpha \mathrm{SiW}_{12} \mathrm{O}_{40}\right] \cdot \mathrm{nH}_{2} \mathrm{O}$ was used as adsorbent of Congo red. In the previous research, optimization of intercalation process of hydrotalcite was conducted using polyoxometalate $\mathrm{H}_{4}\left[\alpha \mathrm{SiW}_{12} \mathrm{O}_{40}\right] \cdot \mathrm{nH}_{2} \mathrm{O}$ (Palapa and Said, 2016). Congo red is an anionic azo dye having IUPAC

\section{Article History}

Received: 25 Septermber 2016

Accepted: 14 December 2016

DOI: $10.26554 /$ sti.2017.2.1.17-21 name as 1-napthalesulfonic acid, 3, 3-[4,4-biphenylebis(azo)] bis (4-amino disodium) salt (Bhoi, 2010). The adsorption process of hydro talcite intercalated polyoxometalate $\mathrm{H}_{4}\left[\alpha \mathrm{SiW}_{12} \mathrm{O}_{40}\right] \cdot \mathrm{nH}_{2} \mathrm{O}$ is intended to determine the effect of $\mathrm{pH}$, kinetic, and thermodynamic parameters by measuring residual concentration and adsorbed amount using UV-Vis spectrophotometer.

\section{EXPERIMENTAL SECTION}

\section{Materials}

The chemicals used are qualified materials such as sodium metasilicate, sodium tungstate, hydrochloric acid, potassium hydroxide, potassium chloride, diethyl ether, sodium hydroxide, sodium carbonate, magnesium nitrate, Congo red dye and aquadest.

\section{Methods}

Synthesis of hydrotalcite, polyoxometalate $\mathrm{H}_{4}[\alpha-$ $\left.\mathrm{SiW}_{12} \mathrm{O}_{40}\right] \cdot \mathrm{nH}_{2} \mathrm{O}$, and hydrotalcite intercalated $\mathrm{H}_{4}[\alpha-$ $\left.\mathrm{SiW}_{12} \mathrm{O}_{40}\right] \cdot \mathrm{nH}_{2} \mathrm{O}$ has been reported previously (Palapa and Said, 2016).

Application of Hydrotalcite intercalated by Polyoxometalate $\mathrm{H}_{4}\left[\alpha-\mathrm{SiW}_{12} \mathrm{O}_{40}\right] \cdot \mathrm{nH}_{2} \mathrm{O}$ as adsorbent of Congo red dye

1. $\mathrm{pH}$

$\mathrm{pH}$ reaction of Congo red adsorption on hydrotalcite intercalated was studied by varying the initial $\mathrm{pH}$ of Congo red solution. $0,1 \mathrm{~g}$ of hydrotalcite and hydrotalcite intercalated each added into $50 \mathrm{~mL}$ of Congo red dye solution $50 \mathrm{mg} / \mathrm{L}$ shaker until 10 minutes using a horizontal shaker. The initial $\mathrm{pH}$ of Congo red was set at 3, 4, 5, 6, 7, 8, 9 and 11 with the addition of $0,1 \mathrm{M} \mathrm{NaOH}$ and $0,1 \mathrm{M} \mathrm{HCl}$. Then the Congo red was separated and the residual concentration after the adsorption process was measured using a UV-Visible spectrophotometer.

\section{Kinetic}

$0,1 \mathrm{~g}$ of hydrotalcite and hydrotalcite intercalate each added into $50 \mathrm{~mL}$ of Congo red dye solution $50 \mathrm{mg} / \mathrm{L}$ shaker with variations in absorption time varied start from 10, 20, 30, 40, 50, 
60, 70, 80, 90, 100, 110 and 120 minutes using a horizontal shaker. The solution of the adsorbed Congo red dye substance was separated by filtration and then measured its concentration by using UV-Vis spectrophotometer. The adsorption rate can be calculated using the Langmuir Equation 1.

3. Thermodinamic

Thermodynamic adsorption of the Congo red dye into hydrotalcite and hydrotalcite intercalated of experiment series as carried out through a series of experiments by varying the concentration and the adsorption temperature. $0,1 \mathrm{~g}$ hydrotalcite intercalated by polyoxometalate added $50 \mathrm{~mL}$ of Congo red dye solution varied concentration 50, 60, 70, 80 and $90 \mathrm{mg} / \mathrm{L}$ while stirred using a horizontal shaker for $30 \mathrm{~min}$ at varying temperatures $30,40,50,60$ and $70^{\circ} \mathrm{C}$. As the control, in different containers as much as $0,1 \mathrm{~g}$ of hydrotalcite added into $50 \mathrm{~mL}$ Congo red dye solution varied of concentration 10, 20, 30, 40 and $50 \mathrm{mg} / \mathrm{L}$. The solution was filtered and Congo red separated from the adsorbent was measured using a UV-Visible spectrophotometer.

\section{Data Analysis}

Hydrotalcite and hydrotalcite intercalated by polyoxometalate were characterizations using FT-IR, XRD, and TG-DTA. The result was applied as adsorbent Congo red dye. The adsorption process was studied by the kinetic and thermodynamic parameter. The kinetics of adsorption was studied by variated of time and adsorption rate was calculated with Langmuir equation:

$\frac{\ln \left(\frac{C_{0}}{C}\right)}{C}=k_{1} \frac{t}{C}+\mathrm{K}$

Where :

$C_{0}=$ Initial concentration of Congo red

$C=$ Concentration of Congo red after the time

$t=$ Time of adsorption

$\mathrm{K}=$ The adsorption equilibrium constant

Thermodinamic Parameters was studied by varied of concentration Congo red dye, adsorption capacity and adsorption energy calculated using Langmuir eq:

$\frac{C}{m}=\frac{1}{b K}+\frac{C}{b}$

$\mathrm{E}=-\mathrm{RT} \ln \mathrm{K}$

Where :

$C=$ The Congo red concentration after adsorption reaches equilibrium
$\mathrm{m}=$ Mol of Congo red adsorption
$0,1 \mathrm{~g}$ hydrotalcite
$\mathrm{K}=$ Equilibrium constant
$\mathrm{b}=$ Adsorption capacity
$\mathrm{E}=$ Adsorption Energy
$\mathrm{R}=$ Boltzmann constant
$\mathrm{T}=$ Temperature

Whereas to find the coefficient value of adsorbat ditribution is used the equation:

$\ln \mathrm{Kd}=\frac{\Delta S}{\mathrm{R}}-\frac{\Delta \mathrm{H}}{R T}$

Where :

$K d=$ Coefficient ditribution adsortion find the coefficient value of adsorbat ditribution (qe/Ce)

$\Delta \mathrm{H}=$ Enthalphy

$\Delta \mathrm{S}=$ Enthrophy

$\mathrm{R}=$ Boltzmann constant

$\mathrm{T}=$ Temperature

The bonds formed between the adsorbate and the adsorbent was studied by FT-IR spectrophotometer.

\section{RESULTS AND DISCUSSION}

Characterization of intercalated layered double hydroxide with $\mathrm{H}_{4}\left[\alpha \mathrm{SiW}_{12} \mathrm{O}_{40}\right] . \mathrm{nH}_{2} \mathrm{O}$ was presented by Palapa and Said (2016) in previous published article. In this results, adsorption of congo red process was systematically reported.

\section{Effect of Initial pH Adsorption of Congo red Dye by Hydrotalcite Mg/Al Intercalated Polyoxometalate $\mathrm{H}_{4}\left[\alpha-\mathrm{SiW}_{12} \mathrm{O}_{40}\right] \cdot \mathrm{nH}_{2} \mathrm{O}$}

$\mathrm{pH}$ adsorption of hydrotalcite and hydrotalcite intercalated to Congo red is shown in Figure 1. Hydrotalcite has optimal $\mathrm{pH}$ at $\mathrm{pH} 9$ with adsorbed concentration of 48,893 ppm with addition of $0.05 \mathrm{~mL}$ of hydrochloric acid. The insertionn double layer hydroxyl has an optimum $\mathrm{pH}$ at $\mathrm{pH} 8$ with an adsorbed concentration of $47.529 \mathrm{ppm}$ with addition of $0.10 \mathrm{~mL}$ of sodium hydroxide. Previously controls for Congo red dyes without adsorbents showed that Congo red to become unstable due to the influence of $\mathrm{pH}$, this is indicated by the color change in Congo red.

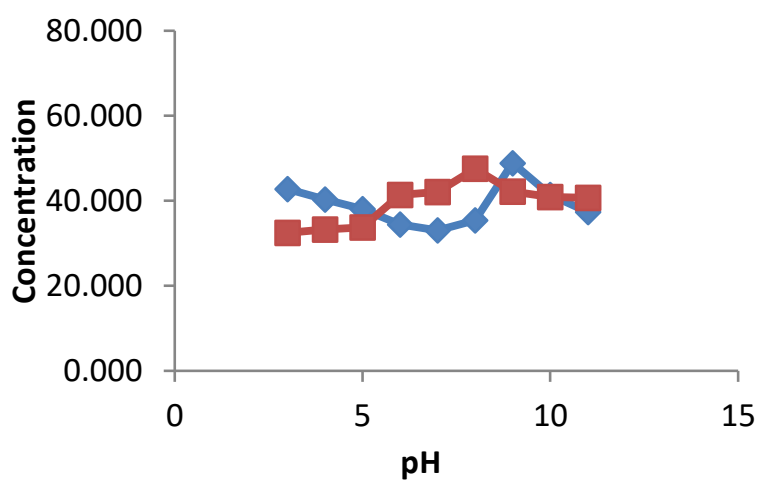

Figure 1. Effect of adsorption $\mathrm{pH}$ of hydrotalcite and hydrtalcite intercalated amount of adsorbed Congo red

Effect of Congo red Adsorption of Time by Hydrotalcite and Hydrotalcite Intercalated

Hydrotalcite intercalated can absorb more adsorbate than hydrotalcite at the same time. At the optimum time of adsorption at $70 \mathrm{~min}$ it is seen that the amount of Congo red dye 
stuff adsorbed by 1.5 times the adsorbent without insertion process. This is because the hydrotalcite intercalated has a larger basal spacing of $9.81 \dot{A}$ than the previous value of $7.4 \dot{A}$. The hydrotalcite intercalated and hydrotalcite curves before the insertion process are presented in Figure 2.

The data obtained in Table 1 show that the hydrotalcite intercalated adsorbent has a higher adsorption rate than the hydrotalcite before intercalated it causes the hydrotalcite intercalated adsorbent to have a greater reactive rate than the hydrotalcite before intercalated.

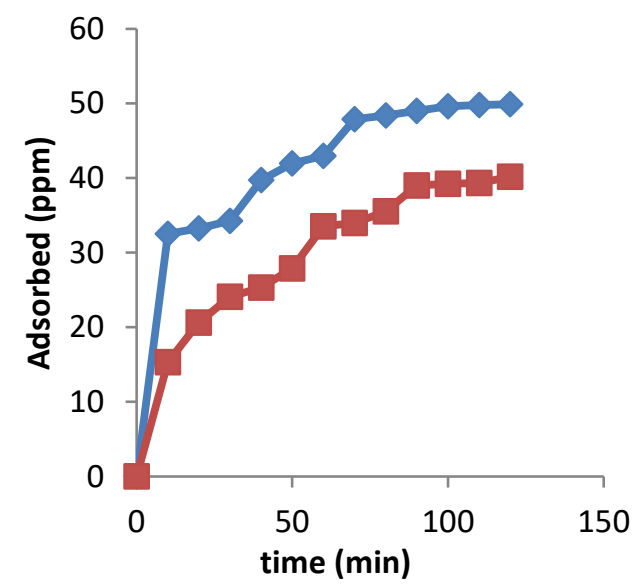

Figure 2. Effect of Congo red Adsorption of Time by Hydrotalcite and Hydrotalcite Intercalated

Table 1. Adsorption rate values for hydrotalcite and hydrotalcite intercalated

\begin{tabular}{lll}
\hline Adsorbent & Parameter \\
\cline { 2 - 3 } & $\mathrm{k}_{1}\left(\mathrm{Sec}^{-1}\right)$ & $\mathrm{R}^{2}$ \\
\hline hydrotalcite & 13,64 & 0,984 \\
$\begin{array}{l}\text { Hydrotalcite } \\
\text { intercalated }\end{array}$ & 51,38 & 0,999 \\
\hline
\end{tabular}

\section{Effect of Concentration and Temperature Adsorption Congo red Dye by Hydrotalcite and Hydrotalcite Intercalated}

Adsorption temperature data by hydrotalcite adsorbent and hydrotalcite intercalated Figures 3 and 4 show the results of the effect of adsorption temperature on the adsorbed Congo red amount of hydrotalcite adsorbent and the hydrotalcite intercalated. Figures 3 and 4 show the effect of temperature and concentration of Congo red dye by a hydrotalcite adsorbent and hydrotalcite intercalated shows that the larger the temperature the greater the amount of adsorbed Congo red, the greater the concentration Then the amount of Congo red adsorbed will increase as well Hydrotalcite adsorbent (control) presented in Figure 3.

The adsorption capacity and adsorption energy of the Congo red dye adsorption process by hydrotalcite and the hydrotalcite intercalated Table 2 explains that the adsorption energy value (E) of Congo red adsorption by hydrotalcite intercalated at visible concentration variations The greater the temperature the more decreasing the adsorption energy $(\mathrm{E})$. This indicates that the adsorption process occurring at the varied temperature undergoes an exothermic condition which means the process releases energy. This state suggests for chemistry states (chemical adsorption) (Vimoses et al, 2009). The determination of the adsorption capacity (b) is determined by the equation 2 which expresses the adsorbent's ability to adsorption the Congo red presented in Table 2. The table shows when the temperature increases, the larger the adsorption capacity.

The subsequent thermodynamic parameters of enthalpy $(\Delta \mathrm{H})$ and entropy $(\Delta \mathrm{S})$ of the Congo red dye adsorption process by the hydrotalcite and hydrotalcite intercalated are presented in Table 3. The table shows the entropy $(\Delta S)$ of Congo red adsorption by hydrotalcite intercalated indicates the degree of irregularity that occurs where large entropy values indicate that the smaller the concentration the degree of irregularity or greater entropy. In addition to the enthalpy value $(\Delta \mathrm{H})$ of Congo red adsorption by the hydrotalcite intercalated presented in Table 3 indicates a decrease as concentration increases.

\section{Study of Adsorption Congo red Dye by Hydrotalcite and Hydrotalcite Intercalated}

The Congo red adsorption interaction study by hydrotalcite adsorbent and the hydrotalcite intercalated was carried out to determine the changes occurring in the adsorbent prior to the adsorption process and after the adsorption process. The change of each adsorbent is seen through characterization using FT-IR spectrophotometer. Figure 5 and 6 show the FT-IR spectrum, before and after the Congo red adsorption process.

Figure 5 shows the comparison of the double layer hydroxy spectrum prior to adsorption and double layer hydroxy after adsorbing Congo red differences in each bonding vibration. Figure 5 after adsorbing Congo red indicates the wave number of $3000-3500 \mathrm{~cm}^{-1}$ indicated that there is a vibration peak of $\mathrm{OH}$ and $\mathrm{NH}$ whereas for Fig. 10 before adsorbing a strong and widespread vibration Congo red is a vibration of - $\mathrm{OH}$ only. The presence of Congo red vibrations is amplified by a peak at 1635 $\mathrm{cm}^{-1}$ which is slightly dilated with low intensity this is due to the bend vibration of $\mathrm{OH}$ which coincides with the vibration of the azo structure $(\mathrm{N}=\mathrm{N})$ which is characteristic of Congo red (Zvezdova, 2014). When compared to Figure 20 before adsorbing the Congo red wave numbers at $1653 \mathrm{~cm}^{-1}$ with high enough intensity and sharpness indicates only $\mathrm{OH}$ bend vibration.

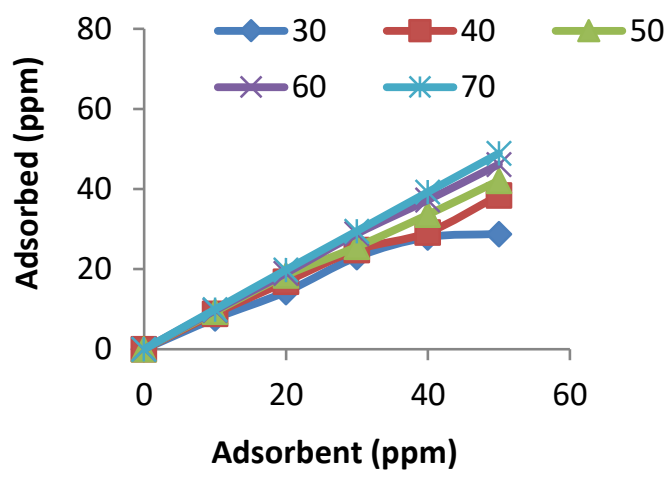

Figure 3. Adsorption Congo red dye varied of concentration and temperature by hydrotalcite 


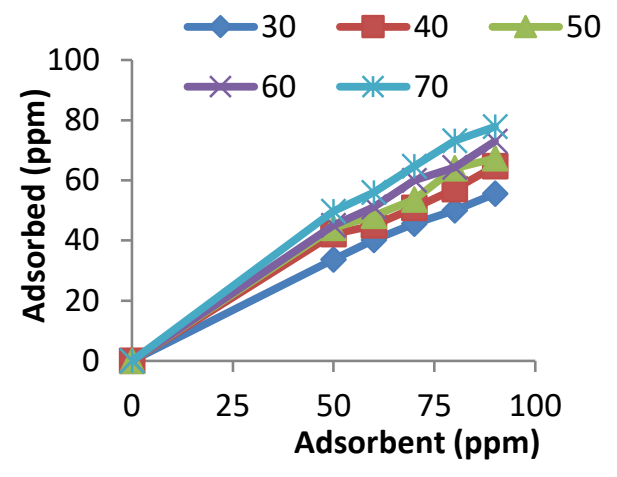

Figure 4. Adsorption Congo red dye varied of concentration and temperature by hydrotalcite intercalated

The Congo red color has a $\mathrm{S}=\mathrm{O}$ vibration shown in Figure 20 after adsorbing Congo red at the peak of vibration with a very low intensity at $1072 \mathrm{~cm}^{-1}$ wave numbers. In addition, the aromatic $\mathrm{C}=\mathrm{C}$ vibration appears at $1481 \mathrm{~cm}^{-1}$ wave numbers. The symmetric stretching vibration of the $\mathrm{N}-\mathrm{O}$ nitrate of the double layer hydroxyl compound with reduced intensity of the double layer hydroxyl before the adsorption process is present at the wave number $1371 \mathrm{~cm}^{-1}$ and the vibration of the $1419 \mathrm{~cm}^{-}$ ${ }^{1}$ wave number indicates the buckling of C-N (Kaur and Rajvir, 2016).

Tabel 2. The adsorption capacity and adsorption energy of the Congo red dye adsorption process by hydrotalcite and the hydrotalcite intercalated

\begin{tabular}{llll}
\hline Adsorbent & ${ }^{\circ} \mathbf{C}$ & $\begin{array}{l}\mathbf{b} \\
(\mathbf{m g} / \mathbf{g})\end{array}$ & $\mathbf{E}(\mathbf{k J} / \mathbf{m o l})$ \\
\hline & 30 & 0.548 & 7.670 \\
& 40 & 1.880 & 7.033 \\
Hydrotalcite & 50 & 2.865 & 6.180 \\
& 60 & 8.130 & 5.720 \\
& 70 & 22.222 & 0.799 \\
\hline Hydrotalcite & 30 & 1.295 & 10.752 \\
intercalated & 40 & 2.092 & 1.826 \\
& 50 & 4.525 & 10.675 \\
& 60 & 3.861 & 3.684 \\
& 70 & 9.091 & 3.861 \\
\hline
\end{tabular}

The double layer hydroxyl adsorbent inserted with the $\mathrm{H}_{4}\left[\alpha \mathrm{SiW}_{12} \mathrm{O}_{40}\right] \cdot \mathrm{nH}_{2} \mathrm{O}$ polyoxometalate compound before and after the Congo red adsorption process is shown in Figure 6. Figure 6 shows the hydroxyl of the double layer inserted prior to the adsorption process shown by the FT-IR spectrum in Fig. 6 before the Congo red adsorption process shows a wider and larger peak when compared to Figure 6 of the double layer hydroxy insertion after the adsorption process has a peak showing the characteristic of the Congo red, There is a widened and strong peak which is a vibration of $-\mathrm{OH}$ and $\mathrm{NH}$ at wave numbers $3000-3600 \mathrm{~cm}^{-1}$. At the same wavelength region the adsorbent before the insertion process has a widened peak which is the vibration of the $\mathrm{OH}$ alone is shown in Fig. 6. Figure
6 hydroxyl layer of hammer after Congo red adsorption process at wave number $2924 \mathrm{~cm}^{-1}$ there is a peak of aromatic benzene vibration from Congo red, peak Vibration for azo structure $\mathrm{N}=$ $\mathrm{N}$ and $\mathrm{OH}$ buckling is present at wave number $1635 \mathrm{~cm}^{-1}$, aromatic $\mathrm{C}=\mathrm{C}$ vibration at wave number $1481 \mathrm{~cm}^{-1}$, for vibration of $\mathrm{NO}$ bend is at wave number $1373 \mathrm{~cm}^{-1}$ and vibration $\mathrm{S}=\mathrm{O}$ is at number Wave $1072 \mathrm{~cm}^{-1}$. The presence of a characteristic peak of Congo red dyestuff vibration indicates that Congo rally absorbed into the adsorbent surface resulting in changes in the FT-IR spectrum before and after the adsorption process.

Tabel 3. The subsequent thermodynamic parameters of enthalpy $(\Delta \mathrm{H})$ and entropy $(\Delta \mathrm{S})$ of the Congo red dye adsorption process by the hydrotalcite and hydrotalcite intercalated

\begin{tabular}{lllll}
\hline Adsorben & $\mathbf{C o}$ & $\mathbf{R}^{\mathbf{2}}$ & $\mathbf{\Delta} \mathbf{H}$ & $\boldsymbol{\Delta} \mathbf{S}$ \\
\hline & $\mathbf{1 0}$ & 0,9280 & 84,511 & 0,281 \\
layered & $\mathbf{2 0}$ & 0,9330 & 76,114 & 0,251 \\
double & $\mathbf{3 0}$ & 0,8910 & 64,059 & 0,212 \\
hydroxide & $\mathbf{4 0}$ & 0,9100 & 70,810 & 0,227 \\
& $\mathbf{5 0}$ & 0,9780 & 84,387 & 0,265 \\
\hline & $\mathbf{5 0}$ & 0,9030 & 40,838 & 0,136 \\
Intercalated & $\mathbf{6 0}$ & 0,9290 & 38,967 & 0,1277 \\
layered & $\mathbf{7 0}$ & 0,9380 & 39,200 & 0,127 \\
double & $\mathbf{8 0}$ & 0,9060 & 39,20 & 0,118 \\
hydroxide & $\mathbf{9 0}$ & 0,9780 & 28,242 & 0,091 \\
& & & &
\end{tabular}

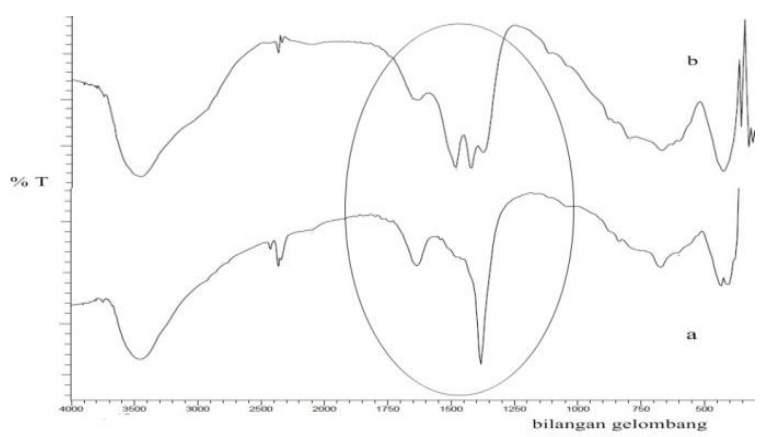

Figure 5. FT-IR spectrum of Hydrotalcite and hydrotalcite intercalated

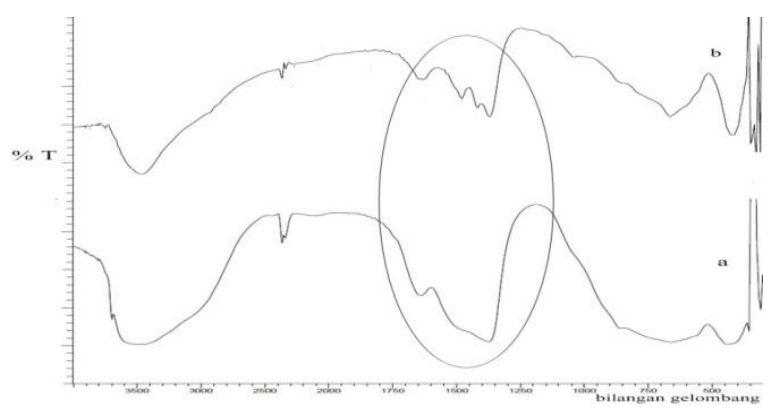

Figure 6. FTIR spectrum of double layer hydroxide inserted polyoxometalate, which adsorp Congo red (A), and double layer hydroxide insertes polyoxometalate. 


\section{CONCLUSION}

Adsorption process of Congo red dye by double layer hydroxy and double layer hydroxy inserted polyoxometalate $\mathrm{H}_{4}\left[\alpha \mathrm{SiW}_{12} \mathrm{O}_{40}\right] \cdot \mathrm{nH}_{2} \mathrm{O}(1: 1)$ showed adsorption rate of 13.64 and $51.38 \mathrm{~min}^{-1}$. While the adsorption thermodynamic parameters for both adsorbents showed an increase in adsorption capacity along with increasing temperature. Other thermodynamic parameters such as enthalpy and entropy decrease with increasing dye concentration. The effect of $\mathrm{pH}$ indicates that the optimum $\mathrm{pH}$ for the double layer hydroxy compound is at $\mathrm{pH}$ 9 , and the polyoxometalate-insulated double-hydroxied hydroxy is at $\mathrm{pH} 8$.

\section{REFERENCES}

Asif, M., Haitao, W., Shuang, D., Aziz, A., Zhang, G., Xiao, F., Liu, H. (2017). Metal Oxide Intercalated Layered Double Hydroxide Nanosphere: With Enhanced Electrocatalytic Activity Towards $\mathrm{H}_{2} \mathrm{O}_{2}$ For Biological Applications. Sensor and Actuators B: Chemical, 239, 243-252.

Bhoi, K, S., 2010. Adsorption Characteristic of Congeored Dye onto PAC and GAC Based on S/N Ratio. Thesis. India: National Institute of Techonology Roulkela.

Duan, X., Lu, J., Evans, D.G. (2011). Assembly Chemistry of Anion-Intercalated Layered Materials. Modern Inorganic Synthetic Chemistry, Chapter 17, 375-404, Elsevier.

Frost, L, Ray., Musumeri, W, A., Bostrom, W., Jones, W., Kooli, F., 1997. Insersition of Electrochemically Reduced Keggin Anion Into LDH. J,Matter Chem. 7(9) : 1937-1939.

Jia, Y., Fang, Y., Zhang, Y., Miras, H.N., Song, F-Y. (2015). Classical Keggin Intercalated Into Layered Double Hydroxides: Facile Preparation and Catalytic Efficiency in Knoevenagel Condensation Reactions. Chemistry A European Journal, 21, 14862-14870.

Kaur, R., and Rajvir, H, K., 2016. Electrochemically Degredation of Congo red from Aquos Solutions. Portugalle Acta. 3(3) : 185-196.
Lesbani, A., Kawamoto, R., Uchida, S., Mizuno, N. (2008). Control of Structures and Sorption Properties of Ionic Crystals of $\mathrm{A}_{2}\left[\mathrm{Cr}_{3} \mathrm{O}\left(\mathrm{OOCC}_{2} \mathrm{H}_{5}\right)_{6}\left(\mathrm{H}_{2} \mathrm{O}\right)_{3}\right]_{2}\left[\alpha-\mathrm{SiW}_{12} \mathrm{O}_{40}\right](\mathrm{A}=$ $\left.\mathrm{Na}, \mathrm{K}, \mathrm{Rb}, \mathrm{NH}_{4}, \mathrm{Cs}, \mathrm{TMA}\right)$. Inorganic Chemistry, 47, 33493357.

Lesbani, A., Fitriliana., Mohadi, R. (2015). Conversion of Cyclohexanone to Adipic Acid Catalyzed by Heteropoly Compounds. Indonesian Journal of Chemistry, 15, 64-69.

Liu, K., Xu, Y., Yao, Z., Miras, H.N., Song, Y-F. (2016). Polyoxometalate-Intercalated layered Double Hydroxides as Efficient and Recyclable Bifunctional Catalysts For Cascade Reactions. Chem. Cat. Chem, 8, 929-937.

Said, M., \& Palapa, N. (2017). Adsorption of Congo Red Using $\mathrm{Mg} / \mathrm{Al}$ Hydrotalcite. Science \& Technology Indonesia, 1(1), 25-28.

Vimoses, Vipasiri., Lei, Shaomin., Jin, Bo., Chow., and Saint, C., 2009. Kinetic Study and Equilibirium Isotherm Analysis of Congo red.

Xie, W., Reng, Hong., Chem, L., 2006. Calcined Mg/Al Hydrotalcite as Solid based Catalysis for Methanolysis of Soybean Oil. Journal of Molecular Catalysis. 246 : 24-32.

Yang, S., Huang, Y., and Li Yu., 2011. Catalytic Application of $\mathrm{H}_{4} \mathrm{SiW}_{12} \mathrm{O}_{40} / \mathrm{SiO}_{2}$ in Synthesis of Acetals and Ketals. Advanced Materials Research, 284-286: 2374-2379.

Zhao, S., Xu, J., Wei, M., and Song, F, Y., 2011. Synergistic Catalysis by Polyoxometalate-Intercalated Layered Double Hydroxide:Oximation of Aromatic Aldehyd. Green Chem. 13 : 384-388

Zvezdova, Dilyana., 2014. Preparation, Characterization and Adsorption Properties of Chitosan Nanoparticles for Congo red as a Model Anionic Direct Dye. Naccni trudove na Rusendev University. 53(10) : 83-87 